\title{
BULGARIAN VILLAGES - AN AUTHENTIC "ARENA" FOR CONDUCTING ACADEMIC SETTLEMENT STUDIES
}

\author{
Milen PENERLIEV \\ Department "Geography, regional development and tourism" University of Shumen, Bulgaria \\ penerliev@yahoo.com \\ Veselin PETKOV \\ Department "Geography, regional development and tourism" University of Shumen, Bulgaria \\ veselin9003@abv.bg
}

\begin{abstract}
The report regards the villages in Bulgaria as a place for conducting geographic field studies and research for geography students of the Shumen University, Bulgaria. The basic terrain methods, the purpose and the main parameters studied, have been indicated. The depopulating villages are the main research target of such field trips, given the threat of oblivion of the settlements' stories, the personal impressions of the local elderly population and the fading of the family memory in those locations. The most endangered elements of the local lifestyle (customs, architecture, migration processes and social activities) have been outlined in the report.

The main results of actual settlement research in various rural areas of Bulgaria have been described. The main findings show that demographic aging is a ubiquitous process; there is a risk of oblivion of customs that once used to be important to the local people and, in this sense, of "impoverishment" of the Bulgarian ethnographic memory and literature. Pressing problematic topics such as the closure of schools have been discussed in the report, while in the same time larger villages have been given as a positive example. Last, but not least, the role of such studies for the practical training of geography students, as well as the fostering of their patriotic spirit, their experience in planning and conducting their own studies in the process of professional realization, have also been taken into account.
\end{abstract}

Key words: rural areas, field studies, research, depopulation

\section{Resumo}

O artigo considera as aldeias na Bulgária como um local de excelência para a realização de estudos de campo geográfico e de pesquisa para estudantes de geografia da Universidade de Shumen, Bulgária. Os métodos essências de trabalho de terreno, a finalidade e os principais parâmetros estudados, estão aqui indicados. As aldeias despovoadas são o principal alvo de pesquisa de tais visitas de campo, dada a ameaça de esquecimento das histórias dos povoados, as impressões e conhecimentos pessoais da população idosa local e o desaparecimento da memória familiar nesses locais. Os elementos mais ameaçados do estilo de vida local (costumes, arquitetura, processos migratórios e atividades sociais) foram delineados no relatório.

Os principais resultados da pesquisa mas aldeias em várias áreas rurais da Bulgária foram descritos. Os principais resultados mostram que o envelhecimento demográfico é um processo omnipresente; há um risco de esquecimento dos costumes que outrora eram importantes para a população local e, nesse sentido, do "empobrecimento" da memória etnográfica e da literatura búlgaras. A insistência em temas problemáticos como 0 fechamento de escolas, é discutida neste artigo, ao mesmo tempo que aldeias de maiores dimensões são apresentadas como exemplo positivo. Por último, mas não menos importante, também foram levados em consideração o papel desses estudos para a formação prática de estudantes de geografia, bem como para a promoção do seu espírito patriótico, da sua experiência no planeamento e na condução dos seus próprios estudos tendo em vista a sua realização profissional.

Palavras-chave: áreas rurais, estudos de campo, pesquisa, despovoamento 


\section{Introduction}

Field trips in human geography are divided into separate categories depending on the criteria used. In essence, these are "on-the-spot" trainings that help firming up newly acquired knowledge, extending its stability, as well as acquiring new skills and competencies. All that predetermines the methods used, the objectives, the region and the specific locations to be visited during the field trip.

Depending on their purpose, field trips in human geography can be:

- Complex field trips - studying, observing and analyzing the territory, applying mostly the system and the complex approach;

- Thematic field trips - studying, observing and analyzing a specific business activity (industry, sector - e.g. power production, tourism, etc.) in a given area.

The complex field trip in human geography is the final stage in the system of geography field trips. For its successful implementation students apply knowledge and skills from all previously conducted field trips. Like all other field trips, the complex field trip is conducted in three stages: preparatory, field research and desk research stage. The emphasis, however, is on the capability of the participants (university and high school students) to select and analyze geographical information about the complex study of the region (statistics, cartographic materials, aerospace photographs, Internet resources, specific bibliographic database of published literature, etc.). The field stage is usually the longest. Students acquire a comprehensive geographical image of the studied area on the basis of personal impressions - starting from the settlements, their inhabitants, the economic specialization of the region, as well as the potentially existing environmental, demographic or socioeconomic problems in the studied area.

The execution of a complex field trip in human geography, regardless of the participants, emphasizes on the complex approach and is expected to form the following competencies in the participants (MIHAYLOVA, PIYASHOVA, PUHOVA, 2012):

- ability to indicate interrelations between the natural, the economic and the social components of the geographical complexes at various territorial levels.

- tolerant perception of the cultural and national traditions, customs and ways of living of the different population groups in different ethno-confessional regions;

- ability to use methods of regional analysis in solving the problems of the territorial units;

- ability to predict socio-economic processes.

The complex field trip is involves a number of methodological and methodical specific features, which are needed for geography students and future geography teachers. For this reason, this paper presents an exemplary field trip with a parallel examination of the participants' acquisition of practical skills, the specific activities for the field trip realization, as well as the delineation of an exemplary field trip route. A constant relation is sought between the field trip itinerary and the formation of the abovementioned skills and competencies which the participants are expected to acquire.

According to the earlier mentioned authors (2012), the choice of an area for the complex field trip in human geography is of particular importance. That choice should consider a sufficiently populated area with different types of inhabitants (in terms of ethnicity, religion, ethnographic groups, 
etc.) and different demographic characteristics. The selected area should exhibit an array of different, more or less actual, economic activities, with complex economic and spatial relations established between the locations to be visited during the field trip.

\section{Methodological aspects of field research in rural areas.}

The authors of this paper are strong supporters of the so-called applied geography. With no intention to elaborate on the numerous definitions of that concept, it is clear, however, that the geography field trips, expeditions and travels are one of the main tools for development of the applicability of geography as a science. The importance and value of field research in geography has never been more obvious given the abundance of problem situations faced by modern societies. Those problems range from extreme natural phenomena (such as floods, droughts and earthquakes), environmental problems such as deforestation and desertification, to problems of society such as crime, poverty, unemployment, depopulation, diseases, increased fertility, etc. On this basis, Pacione (2011) identifies the most important tasks to be completed by applied geography (Table 1). We present those tasks here, since we believe that they are the basis for defining the objectives, the type and the scientific profile of geography field trips and expedition:

Table 1. Main processes and objects in applied geography, subject to field research.

\begin{tabular}{|l|l|}
\hline Natural and environmental hazards & Methods of analysis \\
\hline global warming & remote surveys, statistical data analysis \\
\hline extreme precipitation & computer cartography, modeling \\
\hline earthquakes and volcanism & GPS analysis \\
\hline floods & modeling of the geographical environment \\
\hline extreme climatic phenomena & methods of assessment of the impact on \\
& the population \\
\hline Management of change & Challenges to society \\
\hline water quality assessment & urbanization \\
\hline irrigation & delineation of boundaries \\
\hline combat desertification & geography of poverty \\
\hline combat deforestation & problems of rural areas \\
\hline environmental diversity maintenance & segregation and discrimination \\
\hline environmental impact assessment & city marketing \\
\hline wetlands protection & urban transport and overbuilding issues \\
\hline
\end{tabular}

(Pacione, 2011, with abbreviations and modifications).

It is clear from the table that almost all of the contemporary problems faced by society and nature are subject to study and analysis through field research.

The main approaches to conducting a student field trip are: 
- The historical approach. This is a general scientific method that aims to explain the different processes and phenomena in the surrounding environment, in the context of the "time" category. This category, according to the personal observations of the authors, is difficult for the students to perceive. In the most general example, students find it difficult to perceive geological processes which have taken place over millions of years, in the field (in any given location students may find themselves) the stages in the evolution of geosystems are usually perceived as part of the current processes and phenomena. At the same time, when visiting urbanized areas, the current development of those areas is often based on historically determined factors. Thus, the "time" category takes on a different meaning and content in the two given examples. That is why geography as a science develops private versions of the historical approach. Those are the paleogeographic and the historical-geographical approach. The first one is based on the foundations of historical geology, applicable in the so-called "geological time". In that case, based on various methods (examining relics, radiocarbon dating, etc.), scientists define the positioning of a process or phenomenon in the geological history of geosystems, within a certain geological time period. The historical-geographic approach is related to geographical processes and phenomena that occurred after the emergence of human society. With the help of archeological, toponymical, comparative, dendrochronological and other methods, with even greater precision, scientists date processes, phenomena and objects within the human-occupied geographical environment. When exploring natural geosystems and their components, as a rule, history and evolution go hand in hand. Therefore, according to various authors, there is also a reason to speak of a historical-genetic approach.

The applicability of the historical approach in the context of geography field trips requires sufficient amount of theoretical knowledge. During the visual observation of certain objects in nature and society, university / high school students should be familiar with the peculiarities of the "time" category - in particular - to have some upfront knowledge of the geochronological table, the historical periods, etc. This makes it easier to relate a process or object to a given time period, and vice versa knowing a certain historical period leads to certain expectations for what is seen in the field. Solid cause-effect relationships are built in this way and the concept of remote geological and historical periods in the Earth's and society's history is no longer just an imaginary concept for the students in training.

The system approach. The system approach has been known to science since the late 1940s. Generally speaking, the system is regarded as a complex of elements in constant interaction. Based on the knowledge of the mechanisms of internal connections between the elements of the system, this approach directs the researcher to revealing the integrity of complex objects and phenomena. In geography it is necessary to focus on the distinctive features of the systems as such. Since territoriality is a very typical feature of the systems, it is important for the participants in geography field trips to see, understand and comprehend the internal connections existing within the system being explored, described or simply observed. These interrelations form two categories of system elements: 1) qualitatively heterogeneous but interconnected elements (e.g. geological substrates, soils, etc. in a specific landscape, or the sectors of the economy in a particular socioeconomic region) on the one hand and 2) territorial subunits of a lower order e.g. socio-economic sub- 
regions, industrial units, individual areas of the complex landscape, etc., on the other. In the scientific literature, and in particular that related to the theoretical socio-economic studies, the term complex approach is often used as a synonym of the system approach. While (according to us) there are some differences between those two, these differences represent no significant issue for the immediate purposes of this study. It is important for student researchers to perceive the surrounding environment they are in during field trips and expeditions as a comprehensive well-regulated system. This would facilitate the proper perception of certain processes and phenomena, as well as the regularities in their manifestation.

The regional approach. The regional approach as it is formulated is often confused with the method of regionalization. According to many authors (ANOKHIN and KOSTYEV, 1984, as well as many others), this occurs because the concepts of "approach" and "method" are often used as synonyms. We consider that regionalization (delineation of boundaries, see Table 2) as a method is a complex theoretical and methodological problem of the geographical sciences. In this sense, it has no direct application in geography field trips and expeditions. Here we only mention regional approach as a concept. Students are expected to have a certain notion of it. In socio-economic geography this concept was initially introduced by the Russian scientist N. Kolossovsky, while in geography in general - by Allaev, Baransky, Claval and others. Very often in literature, together with the term "region" / "rayon", the terms "area", "zone" and so forth are also used depending on the purpose of the specific study. According to the contemporary concepts there are two levels of territorial / spatial differentiation, namely - regional and local. Those can vary in scale, as well as in patterns and modes of manifestation of certain processes. That is why students should consider the fact that by exploring or observing an area which exhibits the same regularities and processes within its boundaries, this whole area can be regarded with a great deal of confidence as a territorial unit of some type. By adopting this approach (and not the method of regionalization which has its own tools and specifics), students can apply their critical analysis in existing, distinct natural geographic or socio-economic zones, areas and regions. According to Dimov (2005), regionalization is a scientific result of the objective reality (e.g. altitude-belt zonality) of the existing world. Taking into account this objective reality, the student researchers, by applying the system and the historical approach, must be able to distinguish the territories they visit by origination, development, functioning and purpose.

Methods of observation and information provisioning of the field research in geography. This group of methods has been successfully identified by Isachenko (2004) as the most important, as it is the source of primary information which conclusions, hypotheses and theories are later built upon. These observations can be immediate (in direct contact with the studied object) and indirect (remote), as summarized by Penerliev (2014).

The group of direct observations includes the geography field trips, expeditions and stationary research. Each of those has its specifics and its own private methods. Which of those will be used depends on the objective of the scientific task.

Remote methods allow visual observation of the Earth's surface for a certain purpose. They are divided into aerial and space methods and they are based on using photographic material of varying resolution, scale and altitude of image taking. 
An important feature of this group of methods is the mandatory requirement of keeping record of the observations' results. Keeping a research (observation) diary, making terrain profiles and photographing the studied objects is an indispensable and integral part of the field trips and expeditions. Therefore, for achieving better clarity and easier handling of the gathered primary information, leaflets, tables and other forms of information recording should be developed upfront (see Appendices). The "database" of this activity also includes maps with objects positioned on them and on-the-spot data, laboratory soil and air analyses (if necessary), collecting of rock samples in a certain order, making of a herbarium, etc. These important features of field trips and geographical expeditions will be discussed in detail further on.

In the modern age of "information avalanche", no geographical research can consist of just primary information acquired in field conditions. "Secondary information" that comes from different sources is as important as the primary one. "Secondary information" refers to the various thematic maps, various statistical data from different statistical institutions, GPS maps and data, etc. The provisioning of this vast "avalanche" of diverse information is related to the development of information technology and geoinformatics as a separate discipline (even a scientific field) that provides scientific research with data. There is a huge variety of software products for processing primary information such as Statistica, SPSS, Matlab, etc. For conducting geographical research, the so-called GIS (Geographic Information Systems) software is of major importance. Specific software such as ArcGIS, MapInfo and the like, incorporates a large database set into numerous mapping bases, enabling the making of a variety of thematic maps. GIS thus integrates data appropriate for regionalization, zoning, monitoring, demographic and socio-economic observations, etc. GIS ultimately turns out to be one of the leading methods of the above-mentioned geographical approaches.

The cartographic method. This is a method of geography, applied in almost all scientific disciplines. Therefore, we assume that the student researcher is already familiar with the types of geographic maps, as well as the methods of depiction used in map making. As far as field trips are concerned, it is important to know that the geographic map accompanies the field research in all its stages. The map is an observation document, a source of information, the most appropriate means of displaying the results of direct field observations. In this sense, it is imperative that we obtain a map of the area we are planning to visit prior to the trip itself, as well as a map sheet where the observed objects are immediately positioned on the map.

General scientific methods. The most commonly used methods of this kind during field research are the method of comparison and the method of geographical analogues. The first method we use to establish correlations on the basis of comparison of homogeneous objects (relief forms, settlements, etc.). The comparison method is based on a series of other methods such as the cartographic, the historical, the remote sensing, etc. With the help of those methods we can spot the various qualitative, quantitative, spatial, statistical and other differences between the compared objects. It is one of the most important methods, since the exhibited disparities are used as a base for grouping of different geographical objects by certain indicators, which is in fact the basis of systematization and typology of the geographical objects and phenomena. 
The method of geographical analogues is similar to the previous one. At its core is the comparison of heterogeneous objects, one of which is sufficiently studied. In this way, the properties of the studied object can be largely transferred to the one which is not sufficiently studied one. Very often in field research this method is applied even without suspecting it - for example, when defining a rock sample by comparing its appearance, qualities and properties with another rock sample from an existing mineralogy collection or other source.

Mathematical methods. These are methods that are most commonly used once the field studies have been completed, during the so-called desk research stage. Using mathematical formulas and axioms, a large volume of statistical information is processed. It is important to choose the most appropriate method for the specific purpose of the study. These methods are inextricably linked to both the above-mentioned scientific discipline of geoinformatics, as well as to the modeling method.

The modeling method. This is a universal method of scientific research and field observations. The model is a simplified, incomplete analogue of the object or phenomenon being studied. This way, it is organically associated with the method of geographical analogues. One of the first models is the geographic map. Models can be mathematical, spatial, image-symbolic (the geographic map). While spatial models are real, representing the form and the structure of the studied objects, the mathematical ones are abstract and mostly reveal the quantitative - spatial and temporal - changes concerning certain processes and phenomena. Those methods are important for geography field observations, as with their help we transfer the observed surrounding environment in the field to the auditorium, classroom or scientific laboratory, in an almost authentic way. It is important for future geography teachers to be able to model the natural forms of the observed objects in a sketch, and also - based on collected background information - to be able to make well-founded models of the demographic development of settlements.

The geographical projection method. The geographical projection is a way of extrapolating today's findings from the gathered during field observations baseline data in a future timeframe. For example, when examining the demographic situation of the settlements and discovering the relevant patterns, we can assume their future development for a certain period of time ahead. It should be borne in mind that the more ahead in time we make geographical projections, the less accuracy the projections exhibit. The projection would be more accurate if by analyzing various side factors, we could assume future changes in the examined parameters. On this basis it is possible to amend the geographical projection for greater accuracy. The simplest example of this method is the weather forecast based on a series of climatic data. As it is known, the accuracy of such forecasts is only reliable for a few days ahead.

Basic practical benefits and acquired skills during geography field trips in rural areas.

The execution of such field trips, as well as all other types of geography field trips, passes through three stages (Fig.1).

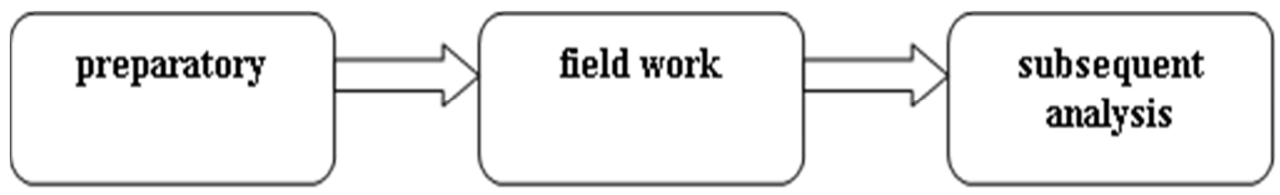

Fig. 1. Stages of geography field trips. 


\section{Preparatory Stage (Methodical guidelines)}

1. Practical skills for selection of locations, objectives and methods of the field trip. This stage of the field trip preparation should be able to answer the question about the opportunities a trip to the Primorska Dobrudzha region offers in acquiring the following competencies by the participants in the field trip after its successful completion (MIHAYLOVA, PIYASHOVA, PUHOVA, 2012):

- ability to identify interrelations between the natural, economic and social components in the geographical complexes at different territorial levels;

- tolerant perception of cultural and national traditions, customs and ways of living of the different population groups in different ethno-confessional regions;

- ability to use regional analysis methods in solving the problems of the territorial units;

- ability to predict socio-economic processes and phenomena.

2. Determining the spatial scope of the field research in geography. This scope depends on the objectives of the field trip, the timing and the realistic possibilities for visiting the selected locations. With regards to the presented human geography field trip model, we assume that Primorska Dobruzha covers a relatively small area within the municipalities of Shabla, Kavarna and Balchik. In it is in that area, where we need to conduct research and achieve the set objectives and complete the research tasks. The studied area is characterized by demographic heterogeneity, a distinctive lifestyle and culture of the local population, as well as negative demographic trends observed in the villages with the highest share of ethnic Bulgarians.

3. Practical skills for delineation of the field trip route. Selection of locations to be visited. This stage of the planning is particularly important. The selection of locations and sites should be such, so that their observation, description and analysis should yield results matching the field trip objectives, as well as enhancing the acquirement of certain competencies by the participants.

4. Practical skills for working with scientific literature and statistical data. This part of the preparatory phase should include:

- making three separate bibliographical reference lists: references concerning the characterization of the settlements; references concerning the population and the demographic situation (demographic structures, movement, etc.); references concerning the economic utilization of the area and its natural conditions. In each list of references, publications related to earlier descriptions of the studied area (expeditions, description of maps, etc.) should be added as well.

- gathering statistical data for certain settlements through the regional statistical offices and the websites of the Population Register offices and the Unified Classification of The AdministrativeTerritorial and Territorial Units. On the basis of a preliminary analysis, "interesting" in terms of demographic and ethnographic profile settlements are selected for visitation.

- reading a scholarly text or applying the so-called "critical reading" of sources listed in the bibliographic reference lists, combined with highlighting the most significant features of the area, in particular those features we expect to observe first-hand in the field. 


\section{Stages of the field research}

After the analysis of the literature and the preliminary statistical data, and in connection to both the objectives of the field trip and the main locations selected for visitation, an itinerary is designed for each day of the trip. Preliminary contact with host organizations (companies, museums, community centers, mayoralties, etc.) is established, presenting the plan and the purpose of the visit. A request is also made (especially to community centers) for their preliminary preparation and the provisioning of sources on the settlement history, literature on the problems studied, interviewing elderly locals, etc.

The main field research is conducted using the methods of 1) the interview and 2) the survey.

1. Conducting surveys. Surveys can vary depending on the purpose of the study or the preassigned task. Here we focus on a not so common type of survey based on the so-called Likert model (Likert scale).

The Likert scale. This is an example of a survey using a questionnaire where a grade assessment of different indicators is applied, following the so-called Likert model. Our main objective is to check the local population's assessment of the development of the settlement as a tourist center. Using that scale, we can assess the perception and impressions of the local population regarding different aspects of local life, regional development, local issues, etc. Instead of the "yes/no" type of possible answers, this type of questionnaire gives the respondents the option to assess a given factor or influence by putting a grade / a mark - most often varying between 1 and 6 .

We can apply such a survey in studying the village of Kamen Briag as a tourist center, considering the following: we are aware that the village is considered the event tourism center of the studied area (with the annual event known as "July morning"); within the village lies the "Yailata" architectural reserve, the village is known for being home to the "Kamenbriashkite babi" folklore group - famous not only in Bulgaria. Students are given the opportunity to conduct the survey, thus acquiring new practical skills and competencies. Respectively, the survey can be conducted during the Kavarna rock festivals in order to get the public's opinion about the festivals' impact on tourism and / or the local community. The application of the survey therefore can be considered multifaceted.

Questionnaire for studying extinct settlements. As of the beginning of 2018 more than 180 settlements in Bulgaria were "erased" from the map of Bulgaria. The study of such settlements and the preservation of their history is an important part of human geography and the related scientific disciplines (ethnography, history, local studies). Quite often, such villages do not have a written history to be bequeathed to the future generations.

One of the most thorough research of extinct settlements was the one done by Guncho Gunchev in the distant 1938. He describes various reasons for the extinction of settlements. Back then - just like in modern times - the extinction of settlements was related to their complete depopulation. An extinct settlement, according to Gunchev, should be considered "a settlement, where the connection between the inhabitants, the housing and the land has been breached". The population starts declining and eventually disappears - according to that same author - for various reasons (natural disasters, economic migrations, etc.). From a modern perspective, the demographic factor plays a leading role. Aging of the population of the villages will lead to the depopulation of a number of 
settlements in the future. This is an outcome which is inevitable for some of the still existing settlements.

In fact, this is a process that takes full effect in Dobrudzha, and in particular in Primorska Dobrudzha. In the preliminary analysis of the statistical data (obtained in advance from the National Statistical Institute (NSI) or from the webpage of the Population Register (www.grao.bg), we indicated such settlements (facing complete depopulation) in Primorska Dobrudzha. Along the already marked route of the field trip, we added the villages of Staevtsi and Tvarditsa. A survey for studying extinct settlements was used. Very often university professors develop and update that kind of survey. In modern conditions and also as part of geography field trips, villages with a population below the critical minimum or those with no inhabitants, completely depopulated in recent years, can be successfully studied. Quite often various infrastructure - buildings, road network, and other technical facilities - is still available in such settlements. We are far from the idea of exploring long-extinct villages that have been missing from the geographic maps for decades. For long-extinct settlements, special scientific field trips is required, but yet such expeditions are possible.

It is important in such field studies - which focus on villages with no population - to photograph and describe churches, cemetery headstones, school buildings (if preserved), village drinking fountains, etc. These are buildings and structures that were strongly built, monolithic in design and often remain intact years after the settlement's desertification. For example, writings on headstones in North Dobrudzha indicate the presence of Bulgarian population in those present-day Romanian territories.

Here is a brief description of our earlier observations in the village of Staevtsi, in support of the discussed need to study such settlements.

\section{THE VILLAGE OF STAEVTSI}

The village sign is visible on the main road to the village of Spasovo and the other villages along the land border with Romania. The village itself is off the road, with no asphalt streets - only dirt roads - while the houses are scattered like separate hamlets. There are preserved and renovated houses, as well as deserted and abandoned ones. No one is to be seen. About 300 meters down on a dirt road, we see a man who tells us that he is from Sofia, and he comes to the village only for the summer. The man shows us another dirt road leading to the church. The church itself has been restored. Shortly after, we see a well-maintained house with stone foundations, a huge yard, a barn with stone walls. Later we learn from the owner that the house dates back from 1901 and only the roof has been renovated. Grandpa Nikolay is 82 years old, and he and his wife maintain the whole property by themselves. He says there is no shop in the village, but they shop from the nearby village of Durankulak, located some 3-4 km away. The old man says that the people actually living in the village are two families (his own and another one), as well as an elderly woman in a neighboring house. The man drives an old Volkswagen which he uses to go to the market in Durankulak. The man himself looks much younger than he is. He says there is no written history of the village. In a way, he himself is the history of the village. In his own words, he repaired the church on his own. However, we found some information about the village of Staevtsi from a local Bulgarian language teacher from the town of Shabla, who was born in Staevtsi. The border of Dobrudzha according to that teacher is represented by a border stone near the town of Balchik. There used to be a 
community center and a school in Staevtsi, the man says. We believe we came upon the old school building. The entirely replaced street lighting in the village does not remain unnoticed, given the lack of roads and inhabitants. It is a village that actually shows the future of the villages in Bulgaria - depopulated, with no infrastructure, with tumbled-down and abandoned buildings.

Source: PETKOV, V., M. PENERLIEV. Scientific expedition "Primorska Dobrudzha - 2011" In: Trips across

Bulgaria (findings from geography field trips and scientific expeditions), published by Shumen University, 2012.

Please, try to locate the village of Staevtsi on the map. (-)

General questionnaire for settlement survey. The questionnaire is designed according to the purpose of the study. It is filled in either by an administrative official or by the interviewer during the interview itself. Often the questionnaire includes questions concerning: the number and age profile of the settlement's population, the availability of a health center and the number of medical personnel, the availability of a community center and the volume of the literary units in the community center library, the availability of educational institutions, infrastructure, etc.

1. Keeping a field diary. Each participant in the expedition should keep a diary where they take notes on personal impressions from the field observations. In the case of each settlement, the field trip participant can focus on the general environment of the settlement. For example, that the settlement can be reached by a run-down, hardly accessible road, or that the former school building is abandoned, or that the common image of the houses is grayish, with predominance of the uninhabited ones. The participants record any positive emotions sensed during the visit to the settlement: for example, one can sometimes spot a number of preserved houses from the Bulgarian Revival era, a well-maintained or a newly-built church, a rich community center library with a friendly community center worker, a renovated central square, friendly and helpful local people, etc. Field trip participants take notes of the conversations with local people (who very often represent the history of the village itself and are quite aware of its problems, the origin of the settlement's name, etc.), as well as any other knowledge acquired during those conversations. Participants are also expected to take photographs of most of the observed sites and buildings. The combination of the right photos and the right notes accompanying them, reestablishes a major part of the impressions, which is needed for the subsequent processing (during the so-called desk research stage) of the gathered base information.

2. Gathering sources of information. Each participant in a human geography field trip is expected to create their own "system" for gathering, classifying and sorting information sources and materials. When arranging visits to museums, community centers, town halls, etc., and briefing the administrative staff about the purpose of the field trip, quite often the host institutions prepare materials regarding the settlement themselves - photographs, promotional materials, etc. All of those locally provided materials are described, if possible xerocopied, while all photos taken during the field trips are also described. All conducted surveys are kept, broken down by type and location. All audio files with conducted interviews are also saved. Wherever it is needed, after the end of each working day, briefings are held, at which the data obtained is discussed, merged and entered in common information sheets, for the purposes of easier processing at the subsequent desk research stage. 


\section{Desk research stage}

The desk research stage is the most important one regarding the consolidation of the practical skills and competencies of the human geography field trip participants. Due to the limited volume of the paper, here we only present some of the ideas concerning that last stage of the research.

1. Practical skills for independent analysis of cartographic and statistical data. Application of mathematical and statistical methods. Selection of the most appropriate methods. The conducted surveys are supplemented by analysis (in the Appendices). Here we suggest additional options for statistical analysis of the obtained demographic and statistical data.

The most commonly used statistical method is the "Median method". It represents the means of the values of the surveyed parameters (average life expectancy, natural growth and other demographic indicators for the entire studied area).

The most common demographic indicators are calculated using mathematical formulas studied in the Geography of Population and Settlements course.

2. Practical skills for analyzing questionnaires, observation sheets and drawing of conclusions. The analysis of the questionnaires should be done separately for each individual question / segment. (see the Likert scale analysis in the Appendices). Conclusions are drawn both for the individual settlements and for the entire studied area. For example: mow many health centers (resp. medical personnel) exist per group of neighboring settlements, how many patients per doctor, etc. The data is visualized through charts, graphs, maps, cartograms and so on. On the basis of the conclusions drawn, geographical projections are then made. For example: what will the number of population of the village of Kamen Briag be by 2025 , or, what will the natural increase rate in Shabla municipality be in 2020 ?

3. Skills for working with specific software. Within a complex field trip in human geography, easier, additional tasks can also be accomplished. For example, the geography students from Shumen University work on a joint-project with NAVTEQ-Bulgaria Company, which creates the MapCreator platform for web-based navigation maps for Nokia Company. During the field trips students enrich the database by marking new objects along their route (healthcare centers, restaurants, new roads, bank offices, etc.).

In conclusion, we can say that this paper only provides basic methodical guidelines for conducting human geography field trips in rural areas. Each element of the field trip, as well as each of the enclosed Appendices are subject to modifications depending on the number and the qualification of the field trip participants, as well as the purpose of the field trip.

Once the essence and the basic features of the geography field trips have been revealed, we can draw conclusions about their positive results in geography education. A study by the University of Marmara, Turkey (BALCI, 2010) points out that after completing each geography field trip, at the subsequent written exams, students tend to:

- $\quad$ submit a smaller number of "blank" answers in their tests (from $32 \%$ to $9 \%$ );

- $\quad$ give correct answer to a higher share of test questions;

- $\quad$ get a higher share of high grades compared to the preliminary assessment (over $70 \%$ ); 
- complete the tests for a shorter period of time;

- increase their ability to define basic concepts.

Our own survey, conducted among Shumen University students in the summer of 2018, confirmed these findings.

\section{Bibliography}

1. BALCI, A. (2010) The impact of geographical trips on geography teaching, Education, Vol. 131, No. 1;

2. ISACHENNCO, A. (2004). Theory and methodology of geography science, Academia, Moskva (In Russian);

3. MIHAYLOVA, N.V., C.N. PIASHOVA, A.G. PUHOV, (2012,) Educational complex economical and geographical practice, сп. География в школе, бр. 5, с.47-52; (in Russian)

4. PACIONE, M. (2011) Applied Geography: Principles and Praxis, Croatian Geographical Bulletin, 73/1, 7 - 28;

5. STORKSDIECK, M. (2001) Differences in teachers' and students' museum field-trip experiences. Visitor Studies Today, 4 (1), p. 8-12.;

6. HOBBS, J. (2010). Fundamentals of World geography, Brooks/Cole, Belmont, USA.

7. PENERLIEV, M. (2014) Field studies in human geography, Shumen, Bulgaria (in Bulgarian)

8. PENERLIEV, M. V. PETKOV. (2018) Student lectures on geography of population and settlements, Shumen, Bulgaria (in Bulgarian). 


\section{Applications}

\section{Research objects in our geographic practices:}

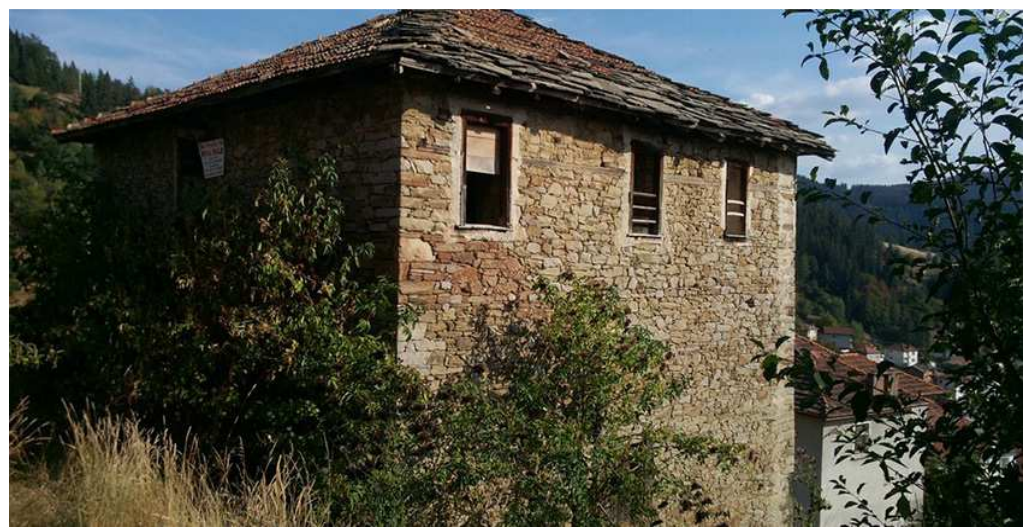

1.Stone house in the Rhodope Mountains there are large deposits of traditional stone.

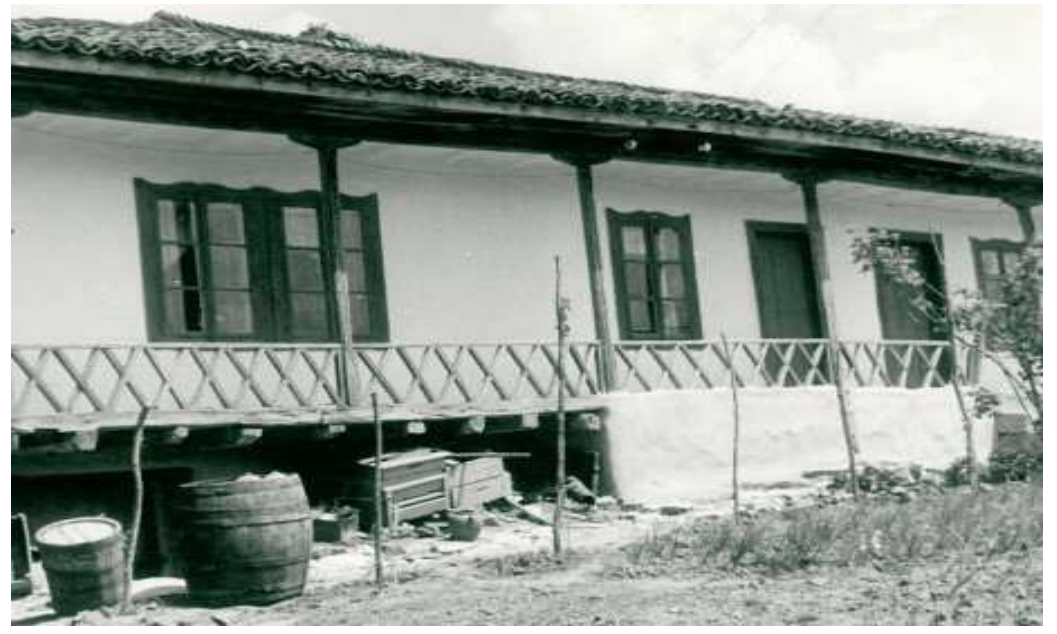

2. Old traditional house in Dobrudja agricultural area - there is no stone.

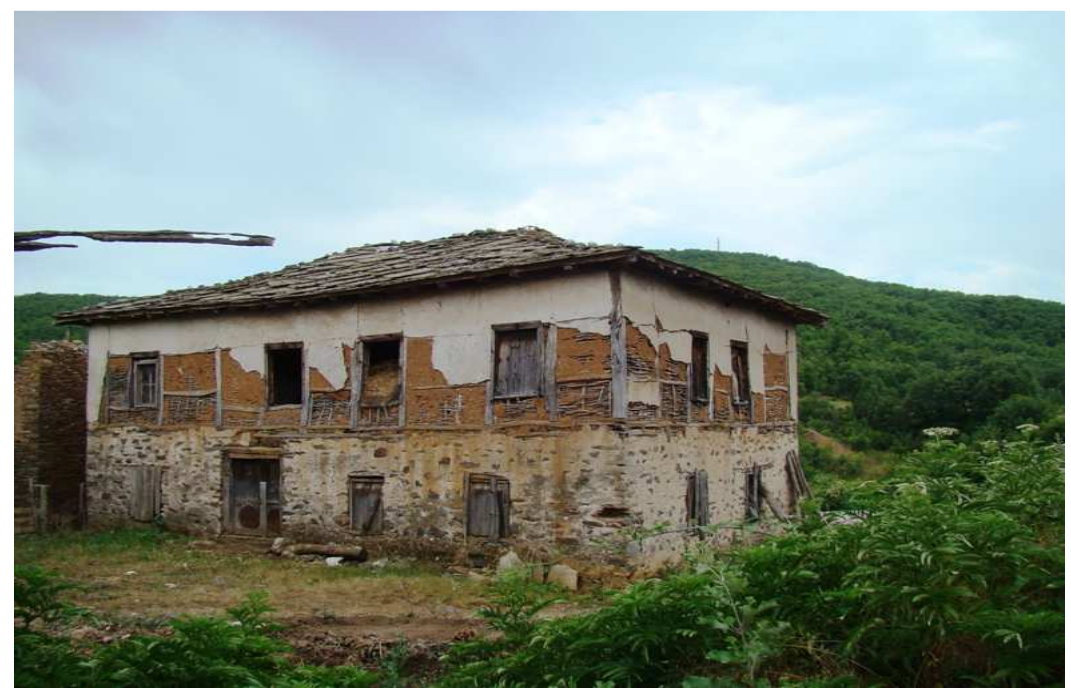

3. The house is composed. 

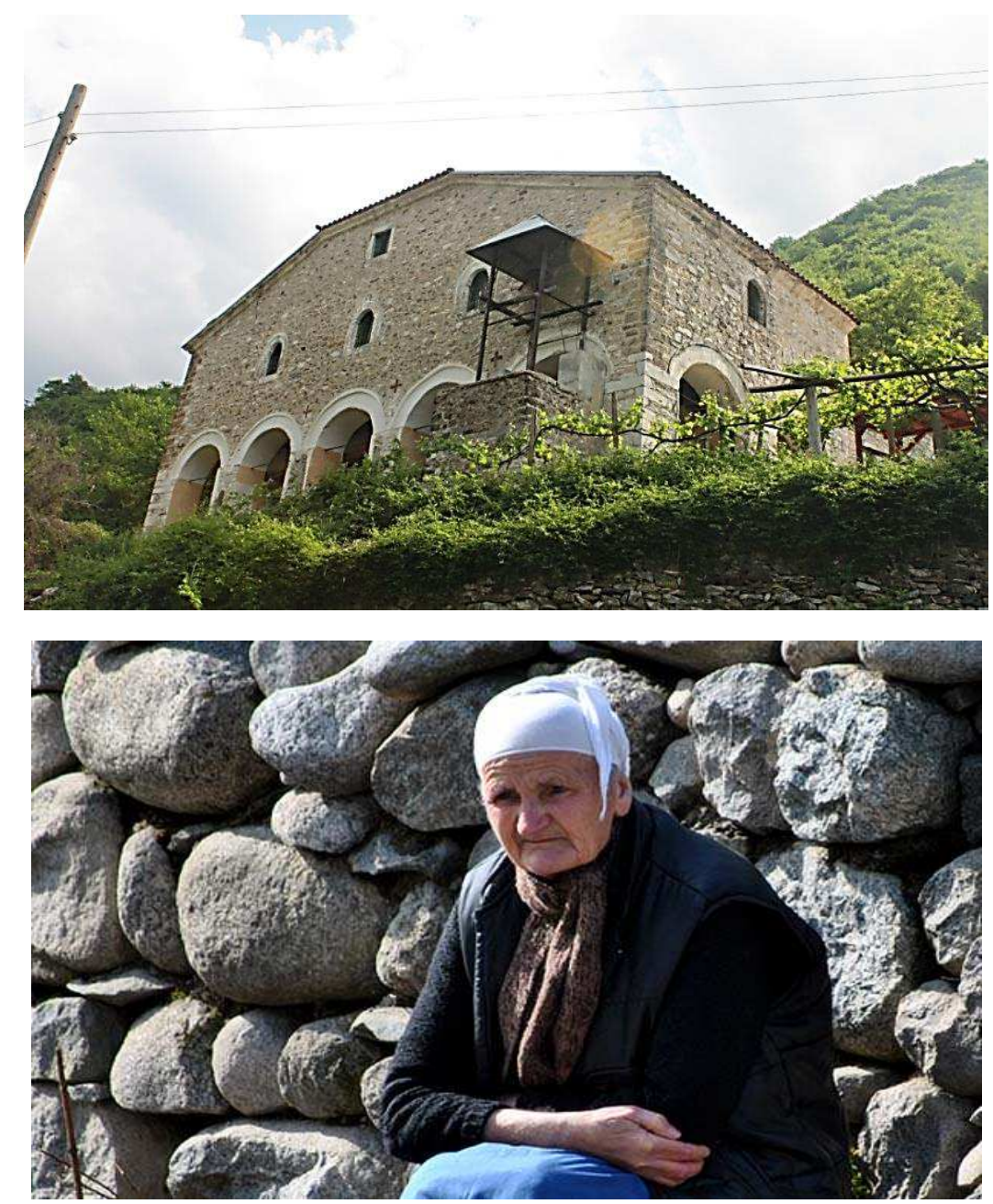

4 and 5. We investigate other material objects: churches, schools, people and etc.

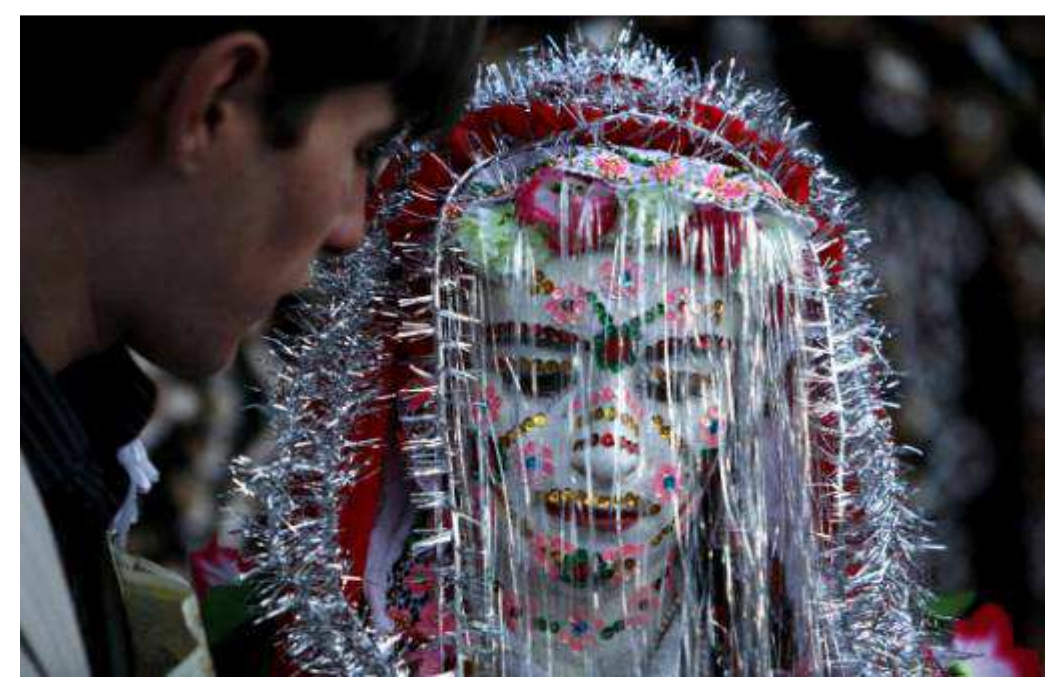

6. "painted" weddings in the Rhodope Mountains 
PENERLIEV, M., PETKOV, V. (2019). Bulgarian Villages - an authentic "arena" for conducting academic settlement studies, The Overarching Issues of the European Space- a strategic (re)positioning of environmental and socio-economic .... Porto, Fac.Letras Univ. Porto. pp. 48-63 (DOI: $10.21747 / 9789898969149 /$ bulg)

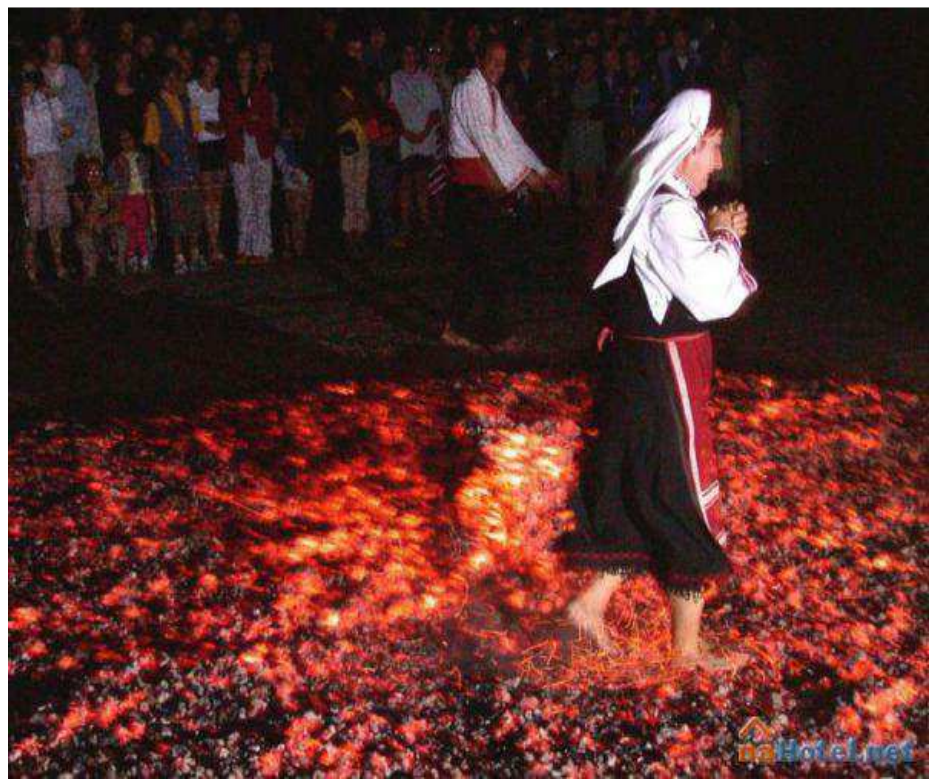

7. Nestinari - walking on the embers. 